\title{
Nar Kabuğu Ekstresinin Sıçanlarda Diyabetik Şartlarda Sepsis ile İndüklenen Akciğer Hasarına Karşı Etkileri
}

\author{
Rüstem Anıl Uğan $i_{1}$, Muhammed Yayla ${ }^{2}$, Harun Ün ${ }^{1}$, Maide Sena Civelek ${ }^{1}$ 4, Pınar Aksu Kılıçle 5 \\ 1 Atatürk Üniversitesi, Eczacılık Fakültesi, Farmakoloji Anabilim Dalı, Erzurum, Türkiye \\ 2 Kafkas Üniversitesi, Tıp Fakültesi, Tıbbi Farmakoloji Anabilim Dalı, Kars, Türkiye \\ 3 Ağrı İbrahim Çeçen Üniversitesi, Eczacılık Fakültesi, Biyokimya Anabilim Dalı, Ağrı, Türkiye \\ 4 Atatürk Üniversitesi, Eczacılık Fakültesi, Lisans programı, Erzurum, Türkiye \\ 5 Kafkas Üniversitesi, Fen Fakültesi, Moleküler Biyoloji Anabilim Dall, Kars, Türkiye
}

Geliș: 14.04.2020; Revizyon: 23.07.2020; Kabul Tarihi: 30.07.2020

\section{$\ddot{0} \mathbf{z}$}

Amaç: Diabetes mellitus (DM), tam veya kısmi insülin yokluğuyla ortaya çıkan bir metabolik hastalıktır. Sepsis, konakçının enfeksiyona veya bir travmaya karşı göstermiş olduğu kompleks enflamatuvar yanıttır. Sepsisin klinik seyri diyabetli hastalarda normal bireylere nazaran daha ağır seyretmektedir. Nar kabuğu ekstresinin yüksek antioksidan kapasitesi, anti-kanser, antimikrobiyal, anti-enflamatuvar ve anti-diyabetik etkinliği vardır. Bu çalışmanın amacı, diyabetik şartlarda sepsis ile indüklenen akciğer hasarına karşı nar kabuğu ekstresinin anti-oksidan ve anti-sitokin özelliklerini araştırmaktır.

Yöntemler: Nar meyvesinin kabukları soyularak kurutuldu. Ekstraksiyon işlemleri uygulandı. Ekstraksiyon çözücüsü olarak etanol kullanıldı. Ekstraksiyon işlemlerinden sonra çözücü buharlaştırıldı ve nar kabuk ekstresi elde edildi. Bu Çalışmada, 30 adet sıçan kullanıldı. Gruplar; Grup 1: Kontrol, Grup 2: Sepsis, Grup 3: DM+S (Diyabet + Sepsis), Grup 4: DM+S+NKE250 (Diyabet + Sepsis + Nar kabuğu ekstresi $250 \mathrm{mg} / \mathrm{kg}$ ), Grup 5: DM+S+NKE500 (Diyabet + Sepsis + Nar kabuğu ekstresi $500 \mathrm{mg} / \mathrm{kg}$ ). Diyabet Tek doz $55 \mathrm{mg} / \mathrm{kg}$ streptozosin ile oluşturuldu. $72 \mathrm{saat}$ sonra açlık kan şekerleri ölçüldü açlık kan şekerleri $250 \mathrm{mg} / \mathrm{dl}$ 'den yüksek çıkan sıçanlar diyabet oldukları kabul edildi. Diyabet tespitinden sonra 10 gün boyunca nar kabuğu ekstresi $250 \mathrm{mg} / \mathrm{kg}$ ve $500 \mathrm{mg} / \mathrm{kg}$ dozlarında oral olarak uygulandı. 10. gün sonunda $5 \mathrm{mg} / \mathrm{kg}$ dozunda lipopolisakkarit intraperitoneal uyguland. 12 saat sonra akciğer dokusu elde edildi. SOD aktivitesi, GSH ve MDA seviyeleri ile TNF- $\alpha$ ve IL-1 $\beta$ mRNA ekspresyonu seviyeleri akciğer dokusunda ölçüldü.

Bulgular: Kontrol grubuyla karşılaștırıldığında, sepsis grubunda, SOD aktivitesi ve GSH seviyesinin azaldığı görüldü. Diyabet+sepsis grubundaki SOD aktivitesi ve GSH seviyesinin hem kontrol hem de sepsis grubuna göre düștüğü bulundu. Sepsis grubunda TNF- $\alpha$ ve IL-1 $\beta$ mRNA ekspresyonu ile MDA seviyesinin Kontrol grubuna göre yükseldiği görüldü. Diyabet+sepsis grubundaki TNF- $\alpha$ ve IL-1 $\beta$ mRNA ekspresyonu ile MDA seviyesinin hem kontrol hem de sepsis grubuna göre arttığı bulundu. Diyabet+sepsis grubuyla karşılaştırıldığında, nar kabuğu ekstresi uygulanan gruplarda doza bağlı olarak SOD aktivitesinin, GSH seviyesinin arttığı ve TNF- $\alpha$ ve IL-1 $\beta$ mRNA ekspresyonu ve MDA seviyelerinin düștüğü görüldü.

Sonuç ve Yorum: Nar kabuğu ekstresi antioksidan ve oksidanlar arasındaki dengeyi düzenlemekte ve sitokin miktarını azaltmaktadır. Bu sebeplerle, antioksidan/oksidan dengesinin bozulduğu ve sitokin firtınasının yoğun görüldüğü diyabet ve sepsis hastalıklarının birlikte olduğu durumlarda nar kabuğu ekstresinin kullanımı akciğer hasarında faydalı sonuçlar verecektir.

Anahtar kelimeler: Nar kabuğu, diyabet, sepsis, akciğer, sıçan

\section{DOI: $10.5798 /$ dicletip.800270}

Correspondence / Yazışma Adresi: Rüstem Anıl Uğan, Atatürk Üniversitesi, Eczacılık Fakültesi, Farmakoloji Anabilim Dalı, 25240, Erzurum, Türkiye email: anil.ugan@atauni.edu.tr / anilugan@hotmail.com 


\title{
The Effects of Pomegranate Peel Extract Against Sepsis Induced Lung Damage Under Diabetic Conditions in Rats
}

\begin{abstract}
Objective: Diabetes mellitus (DM) is a metabolic disease that occurs with complete or partial absence of insulin. Sepsis is the complex inflammatory response of the host against an infection or trauma. The clinical course of sepsis is more severe in patients with diabetes than in normal individuals. Pomegranate peel extract has high antioxidant capacity, anti-cancer, antimicrobial, anti-inflammatory and anti-diabetic activity. The aim of this study is to investigate the anti-oxidant and anti-cytokine properties of pomegranate peel extract in sepsis induced lung damage under diabetic conditions.
\end{abstract}

Method: The pomegranate peel was decorticated and dried. Extraction processes were applied. Ethanol was used as extraction solvent. After extraction, solvent was evaporated and the pomegranate peel extract was obtained. In our study, 30 rats were used. Our Groups are; Group 1: Control, Group 2: Sepsis, Group 3: DM + S (Diabetes + Sepsis), Group 4: DM + S + NKE250 (Diabetes + Sepsis + Pomegranate peel extract 250 $\mathrm{mg} / \mathrm{kg}$ ), Group 5: DM + S + NKE500 (Diabetes + Sepsis + Pomegranate peel extract $500 \mathrm{mg} / \mathrm{kg}$ ). Diabetes was induced with a single dose of $55-\mathrm{mg} / \mathrm{kg}$ streptozocin. After 72 hours, fasting blood glucose levels were measured. Rats with fasting blood glucose higher than $250 \mathrm{mg} / \mathrm{dl}$ were considered as diabetes. The pomegranate peel extract was administered orally at doses of $250 \mathrm{mg} / \mathrm{kg} \mathrm{and} 500 \mathrm{mg} / \mathrm{kg}$ for $10 \mathrm{days}$ after diabetes detection. Lipopolysaccharide was intraperitoneal administered at the dose of $5 \mathrm{mg} / \mathrm{kg}$ at the end of the 10 th day. Lung tissue was dissected out after 12 hours. SOD activity, GSH and MDA levels and TNF- $\alpha$ and IL-1 $\beta$ mRNA expression levels were measured in lung tissue.

Results: It was seen that SOD activity and GSH levels decreased in the sepsis group when compared with the control group. It was found that SOD activity and GSH level in diabetes + sepsis group decreased when compared to both control and sepsis groups. TNF- $\alpha$ and IL-1 $\beta$ mRNA expression and MDA level increased in the sepsis group when compared to the Control group. It was found that TNF- $\alpha$ and IL-1 $\beta$ mRNA expression and MDA level in diabetes + sepsis group increased when compared to both control and sepsis groups. When compared with the diabetes + sepsis group, it was observed that the SOD activity, GSH level increased and TNF- $\alpha$, IL-1 $\beta$ mRNA expression and MDA levels decreased depending on the dose in groups that administered pomegranate peel.

Conclusion: Pomegranate peel extract shows anti-oxidant and anti-inflammatory activity by regulating the balance between antioxidants and oxidants and reducing the amount of cytokines. For these reasons, the use of pomegranate peel extract will yield beneficial results on lung damage in case that diabetes and sepsis diseases coexist, which the antioxidant/oxidant balance is disturbed and cytokine storm is intense.

Keywords: Pomegranate peel, diabetes, sepsis, lung, rat.

\section{GíRiş}

Diabetes mellitus (DM), tam veya kısmi insülin yokluğuyla ortaya çlkan bir metabolik hastalıktır ${ }^{1,2}$. Diyabetin en önemli belirtilerinden hiperglisemi çoklu organ hasarlarına sebebiyet verir ${ }^{3}$. Ayrıca diyabetli hastalar koroner arter hastalığı, çeşitli bakteriyel enfeksiyonlar gibi bazı hastalıklara karşı açı hale gelmektedir ${ }^{3,4}$. Bu hastalıkların klinik seyri diyabetli hastalarda normal bireylere nazaran daha ağır seyretmektedir ${ }^{5}$. Dahası, diyabetli hastaların bağışıklık sistemi de etkilenmektedir. $\mathrm{Bu}$ nedenlerden dolayı, herhangi bir hastalığı olmayan bireylere göre diyabetik hastaların sepsise ve enfeksiyona yakalanma ihtimalleri daha yüksektir ${ }^{3}$. Çünkü aşırı düzeydeki kan glukozu çeşitli dokulara saldırır ve bu dokulardan sitokin ve reaktif oksijen radikallerinin salıverilmesini uyarır ${ }^{6,7}$.
Sepsis, konakçının enfeksiyona veya bir travmaya karşı göstermiş olduğu kompleks enflamatuvar yanıttır ${ }^{8}$. Sepsis, dünya genelinde yüksek ölüm oranına sahiptir ve yoğun bakım ünitelerini çokça meşgul eden bir konudur9. Sepsiste patofizyolojik olarak immün yanıtın düzenlenememesi, dokunun az kanlanmasına ve koagülasyona yol açmakta ve sonuç olarak SIRS (Systemic Inflammatory Response Syndrome), çoklu organ yetmezlikleri ve septik şok görülmektedir ${ }^{10}$. Sepsisten özellikle akciğer etkilenmekte (olguların \%40'ı kadar) ve ölümlerin birçoğu bu hayati organda gelişen akut akciğer hasarı ve akut solunum zorluğuna bağlı gelişmektedir ${ }^{3}$. Sepsiste serbest oksijen radikalleri ile beraber tümör nekroz faktör alfa (TNF- $\alpha$ ) ve interlökin (IL) gibi enflamatuvar sitokinlerin üretiminin artması söz konusudur ${ }^{11}$.

Nar (Punica granatum L.) birçok ülkede yaygın bir şekilde yetiştirilmektedir. Narın diyetle 
alındığında çok farklı faydalarının olması popülerliğini gün geçtikçe artırmaktadır ${ }^{12}$. Son yıllarda yapılan bilimsel çalışmalar, narın; kanser, diyabet, kardiyovasküler hastalıklar ve enfeksiyon gibi hayatı tehdit edici hastalıkları önleyici ve azaltıcı etkilerinin olduğu gösterilmiştir ${ }^{13}$. Antioksidan özelliğinden dolayı nar ekstraktının sepsiste faydalı etkilerinin olduğu da bilinmektedir ${ }^{14}$. Narın sadece yenilebilir kısımları değil kabuğu gibi yenilmeyen kısımları da yüksek miktarda aktif madde içermektedir ${ }^{15}$. Hatta narın kabuğu, meyve suyundan daha fazla polifenolik bileşik içermektedir ${ }^{16}$. Nar kabuğu ekstresinin yüksek antioksidan kapasitesi vardır ${ }^{16,17}$. Antioksidan aktivitesinin yanında, nar kabuğu ekstresinin anti-kanser ${ }^{12}$ antimikrobiyal ${ }^{18,}$ antienflamatuvar ${ }^{19}$ ve anti-diyabetik etkinliğe sahip olduğu bilinmektedir ${ }^{12}$. Bu gibi biyolojik etkileri bilinen nar kabuğu ekstresinin, bağışıklık sistemini bozan bir hastalık olan diyabet varlığına ek oluşacak bir sepsis durumunda yeterince faydalı etkiler gösterebileceği henüz araştırılmamıştır.

$\mathrm{Bu}$ çalışmanın amacı, diyabetik şartlarda sepsis ile indüklenen akciğer hasarına karşı nar kabuğu ekstresinin anti-oksidan ve anti-sitokin özelliklerini araştırmaktır.

\section{YÖNTEMLER}

\section{Bitki Ekstraksiyonu}

Ticari olarak satın alınan nar meyvesinin kabukları soyularak, doğrudan güneş ışı̆̆ almayan ve kuru hava akımının sağlandığı bir ortamda seyrek serilerek kurutuldu. Kurutulan kabuklar ögütücüde öğütüldü. Ögütülen kabuklardan 50 gram alınarak ekstraksiyon çözücüsü ile yıkanan kartuş içerisine konuldu. Kartuş 500 mL'lik Soxhlet ekstraktörü içerisine yerleştirildi ve kaynama balonuna $650 \mathrm{~mL}$ çözücü konuldu. Çözücü berraklaşana kadar ekstrakte (20-30 sifon) edildi. Eksraksiyon çözücüsü olarak etanol kullanıldı. Elde edilen sıvı eksrakt mavi band süzgeç kâğıdından süzülerek partikülleri uzaklaştırıldıktan sonra, rotary evaporatör ile 50-55 ${ }^{\circ} \mathrm{C}^{\prime}$ de çözücü uçuruldu. Çözücüsünden tamamen uzaklaştırılan nar kabuk ekstraktı tartılıp saklama kutusuna konularak $+4{ }^{\circ} \mathrm{C}$ 'de muhafaza edildi ${ }^{20}$.

\section{Hayvanlar}

Bu çalışmada, 250-300 gram ağırlığında, 30 adet erkek Albino Wistar sıçan kullanıldı. Sıçanlar Atatürk üniversitesi deney hayvanları araştırma merkezinden temin edildi. Sıçanlar plastik kafeslerde altlarında talaşla barındırıldı. Barındıkları yerin sıcaklığı $22 \pm 1^{\circ} \mathrm{C}$ ve aydınlığı $12 / 12$ saat gece/gündüz döngüsünde olacak şekilde ayarlandı. Hayvanlara standart yem ve çeşme suyu ad libitum verildi. Laboratuvar hayvanlarının kullanımında ve bakımında ulusal rehberlere ve etik kurallara uygun davranılmıştır. Etik kurul izni Atatürk üniversitesi deney hayvanları yerel etik kurulundan alınmıştır. Etik kurul izin belge numarasi: 2020/2-42.

Sıçanlar rastgele 5 gruba ayrıldı. Grup başına hayvan sayısı 6'dır.

\section{Gruplar:}

Grup 1: Kontrol

Grup 2: Sepsis

Grup 3: DM+S (Diyabet + Sepsis)

Grup 4: DM+S+NKE250 (Diyabet + Sepsis + Nar kabuğu ekstresi $250 \mathrm{mg} / \mathrm{kg}$ )

Grup 5: DM+S+NKE500 (Diyabet + Sepsis + Nar kabuğu ekstresi 500 mg/kg)

\section{Streptozosin ile Oluşturulan Diyabet Modeli}

Diyabet intraperitonel (i.p.) streptozosin (STZ) uygulamasıyla oluşturuldu (grup 3, 4 ve 5'te). Tek doz $55 \mathrm{mg} / \mathrm{kg} \mathrm{STZ,} \mathrm{taze} \mathrm{hazırlanan} \mathrm{0,1} \mathrm{M}$ pH:4,5 olan sitrat tamponunda çözündürülerek uygulandı. İlaç taşıyıcı tampon kontrol ve sepsis gruplarına uygulandı. STZ enjeksiyonundan 72 saat sonra açlık kan şekeri seviyeleri kuyruk 
veninden alınan örneklerden glukometre (On call Plus) ile ölçüldü. Açlık kan şekerleri 250 mg/dl'den yüksek çlkan sıçanlar diyabet oldukları kabul edildi21,22. Diyabet oluştuğu tespit edildikten sonra nar kabuğu ekstresi 250 $\mathrm{mg} / \mathrm{kg}$ ve $500 \mathrm{mg} / \mathrm{kg}$ dozlarında gastrik gavaj ile oral olarak 10 gün boyunca uygulandı. Ekstrelerin uygulanması: Sivı haldeki ekstre (dozlara göre hesaplanarak) belirlenen miktarlarda tartıldı ve saf suda çözündürülerek, sıçan başına $1 \mathrm{ml}$ olacak şekilde uygulandı. Kontrol, sepsis ve $\mathrm{DM}+\mathrm{S}$ gruplarına aynı hacimde saf su uyguland.

\section{Lipopolisakkarit ile Oluşturulan Sepsis Modeli}

Diyabet oluştuğu tespit edildikten 10 gün sonra, $5 \mathrm{mg} / \mathrm{kg}$ dozunda lipopolisakkarit (LPS) kontrol grubu hariç diğer gruplara uygulandı. Lipopolisakkarit serum fizyolojikte çözülerek i.p. uygulandı. Sepsis oluşturulduktan 12 saat sonra deney sonlandırıldı. Bu amaçla, 100 $\mathrm{mg} / \mathrm{kg} \quad$ ketamin+15 $\mathrm{mg} / \mathrm{kg} \quad$ ksilazin kombinasyonuyla anestezi yapılan hayvanların akciğerleri çıkarıldı ve biyokimyasal ve moleküler analizler için -80을 de saklandı.

\section{Akciğer Dokusunda Biyokimyasal Parametrelerin Ölçülmesi}

Tüm akciğer dokuları TissueLyser II (Qiagen, Hilden, Germany) cihazında sıvı azot yardımıyla toz haline getirildi. Yaklaşık $100 \mathrm{mg}$ toz doku 1 $\mathrm{ml}$ fosfat buffer salinde (PBS) homojenize edildi ve santrifüj edildi. Akciğer doku süpernatantında, süperoksit dismutaz (SOD) aktivitesi 23 , glutatyon (GSH) ve malondialdehit (MDA) seviyeleri daha önceki çalışmalarımızdaki gibi enzime bağlı immünosorban analiz (ELISA) metodu kullanılarak manuel olarak ölçüldü3 ${ }^{3}$. Protein miktarları Lowry yöntemi kullanılarak manuel ölçüldü. Tüm veriler, mg proteine oranlanarak ortalama \pm standart sapma (SD) olarak gösterildi.

\section{Total RNA saflaştırılması ve cDNA sentezi}

mRNA sentezi ve komplementer DNA (cDNA) önceki çalışmalarımızdaki yöntemlere göre gerçekleştirildi 6,24,25. Homojenize edilen akciğer dokuları grup içi havuz yapılarak $20 \mathrm{mg}$ dokudan mRNA elde edildi. Total mRNA, RNeasy Mini Kit kullanarak QIACUBE (Qiagen, Hilden, Germany) cihazında üreticinin talimatları doğrultusunda saflaştırıldı. RNA örnekleri High Capacity cDNA Reverse Transcription Kit (Applied Biosystems, CA, USA) kullanılarak ters transkripte edildi.

Gen ekspresyonunun rölatif değerlendirilmesi

TNF- $\alpha$ ve IL-1 $\beta$ 'nin nispi mRNA ekspresyon analizi Taqman Gene Expression kit kullanılarak StepOne Plus Real Time PCR (Applied Biosystems) cihazında gerçekleștirildi. $\beta$-actin housekeeping gen olarak kullanıldı. RealTime PCR'da sıçan için üretilen TNF- $\alpha$, IL$1 \beta$ ve $\beta$-actin primerleri kullanılarak spesifik tespit yöntemi uygulandı. Primerlerin temin edildiği markaya göre Primerlerin oligonükleotid dizilimi veya temin edilen kodları şöyledir: Rat TNF- $\alpha$; forward, 5'-GCT CCC TCT CAT CAG TTC CA-3'; reverse, 5' CTC CTC TGC TTG GTG GTT TG-3' (Primer Design), rat IL-1 $\beta$; Rn00580432_m1 (Life Tech.), rat $\beta$ actin; forward, 5'-TGG TGG GTA TGG GTC AGA AG-3'; reverse, 5'-GAC AAT GCC GTG TTC AAT GG-3' (Primer Design). Her örnek için, $9 \mu \mathrm{l}$ cDNA (100 ng), $1 \mu \mathrm{l}$ Primer Perfect Probe mix ve $10 \mu \mathrm{l}$ QuantiTect Probe PCR Master mix (Qiagen, Hilden, Almanya) kullanılarak her bir hedef gen için ayrı ve üç tekrar olacak şekilde 96 kuyucuklu bir optik plaka kullanılarak yapıldı. Her $20 \mu l^{\prime}$ lik reaksiyonda. Plakalar, $50^{\circ} \mathrm{C}^{\prime}$ de 2 dakika ve $95^{\circ} \mathrm{C}$ 'de 10 dakika isttıldı ve daha sonra $94^{\circ} \mathrm{C}$ 'de 15 saniye ve $60^{\circ} \mathrm{C}$ 'de 60 saniye boyunca 40 döngü uygulandı. Tüm ekspresyon verileri, $2-\Delta \Delta$ Ct yöntemi kullanılarak kontrol grubuna kıyasla kat değişimi olarak ifade edildi ${ }^{26}$.

\section{İstatistiksel Analiz}


Çalışmanın verileri IBM SPSS 20.0 istatistik programında değerlendirildi. Biyokimyasal ve moleküler analiz verilerine normal dağılım testleri uygulandı ve skewness ve kurtosis değerlerinin -2 ve 2 arasında olmasıyla verilerin normal dağıldığı görüldü ${ }^{27}$. Varsayımlar karşılandığından sonuçlar tek yönlü varyans analizine tabi tutuldu ${ }^{28}$. Gruplar arasındaki farklar Duncan çoklu karşılaştırma testi ile belirlendi ( $\mathrm{p}<0.05)$. Tüm sonuçlar her grup için ortalama \pm SD olarak ifade edildi.

\section{BULGULAR}

\section{Akciğer Dokusunda Antioksidan Parametre Sonuçları}

Kontrol grubundaki değerlerle (SOD: 27,43 $\pm 2,17$ GSH: 2,55 $\pm 0,19$ MDA: 0,87 $\pm 0,02$ ) karşılaştırıldığında, sepsis grubunda SOD aktivitesinin $(14,19 \pm 0,72)$ ve GSH seviyesinin $(0,86 \pm 0,12)$ anlamlı bir şekilde azaldığı, MDA seviyesinin $(1,67 \pm 0,07)$ anlaml bir şekilde yükseldiği görüldü. Kontrol ve sepsis gruplarıyla karşılaştırıldığında, $\mathrm{DM}+\mathrm{S}$ grubunda SOD aktivitesinin $(11,63 \pm 1,15)$ ve GSH seviyesinin $(0,77 \pm 0,06)$ anlaml bir şekilde azaldığı, MDA seviyesinin $(2,28 \pm 0,08)$ ise anlamlı bir şekilde arttığı görüldü. $\mathrm{DM}+\mathrm{S}$ grubuyla karşılaştırıldığında ise, nar kabuğu ekstresi uygulamasının SOD aktivitesini (DM+S+NKE250: 16,81 $\pm 0,65, \mathrm{DM}+\mathrm{S}+\mathrm{NKE} 500$ : $25,49 \pm 0,89)$ ve $G S H$ seviyesini $(D M+S+N K E 250$ :

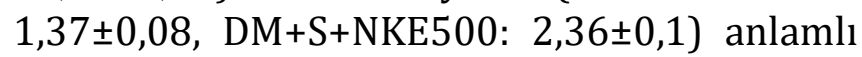
bir şekilde yükselttiği ve MDA seviyesini (DM+S+NKE250:

$1,42 \pm 0,09$, $\mathrm{DM}+\mathrm{S}+\mathrm{NKE} 500: 0,93 \pm 0,08)$ anlamlı bir şekilde azalttığ görüldü. SOD, GSH ve MDA sonuçlarının tümünde, DM+S+NKE250 ve $\mathrm{DM}+\mathrm{S}+\mathrm{NKE} 500$ grupları arasında anlamlı bir farklılık olduğu görüldü. Bunun sonucunda, nar kabuğu ekstresinin etkilerinin doza bağlı olduğu bulundu (Grafik 1).

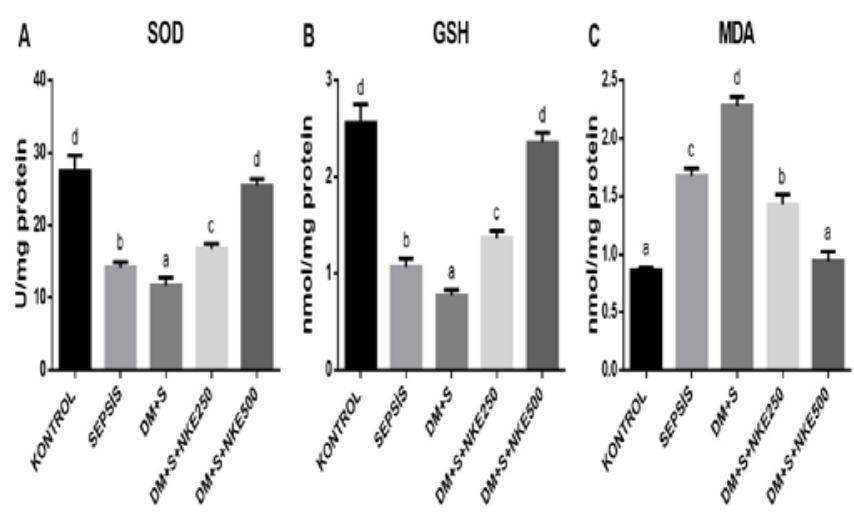

Grafik 1: Nar kabuğu ekstresinin akciğer dokusunda SOD aktivitesi, GSH ve MDA seviyesi üzerine etkileri. Aynı harfe sahip barlar istatistiksel olarak farklı değildir; harfleri farklı olan barlar Duncan testine göre gruplar arasında anlamlı farklılıklar olduğunu gösterir $(\mathrm{p}<0.05)$. Sonuçlar ortalama $\pm S D$ 'dir. $n=6$. DM: Diabetes Mellitus, S: Sepsis, NKE250: Nar kabuğu ekstresi $250 \mathrm{mg} / \mathrm{kg}$, NKE500: Nar kabuğu ekstresi 500 mg/kg.

\section{Akciğer Dokusunda TNF- $\alpha$ ve IL-1 $\beta$ mRNA Ekspresyon Sonuçları}

Kontrol grubundaki değerlerle (TNF- $\alpha$ : $1 \pm 0,01$,

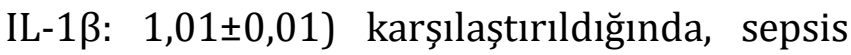
grubunda TNF- $\alpha \quad(16,62 \pm 0,43)$ ve IL-1 $\beta$ $(13,85 \pm 0,45)$ mRNA ekspresyonlarının anlamlı bir şekilde arttığı bulundu. Kontrol ve sepsis gruplarıyla karşılaştırıldığında, DM-S grubunda TNF- $\alpha(24,16 \pm 0,81)$ ve $\operatorname{IL}-1 \beta(17,07 \pm 0,47)$ mRNA ekspresyonlarının anlamlı bir şekilde yükseldiği görüldü. DM-S grubuna göre, nar kabuğu ekstresi uygulanan gruplarda doza bağlı olarak TNF- $\alpha$ (DM+S+NKE250: 10,72 $\pm 0,38$, DM+S+NKE500: $4,04 \pm 1,47)$ ve IL-1 $\beta$ (DM+S+NKE250: $9,81 \pm 0,51, \quad \mathrm{DM}+\mathrm{S}+\mathrm{NKE} 500$ : $3,33 \pm 0,61$ ) mRNA ekspresyonu seviyelerinin anlamlı bir şekilde düştüğü tespit edildi. TNF- $\alpha$ ve IL-1 $\beta$ mRNA ekspresyon sonuçlarında, $\mathrm{DM}+\mathrm{S}+\mathrm{NKE} 250$ ve $\mathrm{DM}+\mathrm{S}+\mathrm{NKE} 500$ grupları arasında anlamlı bir farklılık olduğu bulundu. Bunun sonucunda, nar kabuğu ekstresinin etkilerinin doza bağlı olduğu görüldü (Grafik 2). 

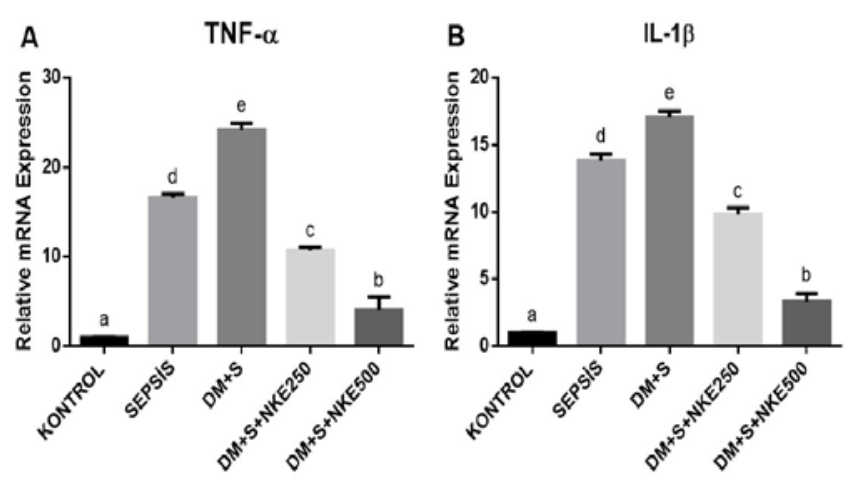

Grafik 2: Nar kabuğu ekstresinin akciğer dokusunda TNF- $\alpha$ ve IL-1 $\beta$ mRNA ekspresyon seviyeleri üzerine etkileri. Aynı harfe sahip barlar istatistiksel olarak farklı değildir; harfleri farklı olan barlar Duncan testine göre gruplar arasında anlamlı farklılıklar olduğunu gösterir ( $\mathrm{p}$

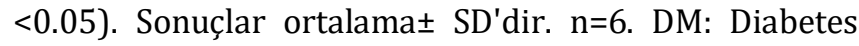
Mellitus, S: Sepsis, NKE250: Nar kabuğu ekstresi 250 mg/kg, NKE500: Nar kabuğu ekstresi 500 mg/kg.

\section{TARTIŞMA}

Nar (Punica granatum L.) Afrika, güney ve doğu Asya, Kafkaslar, kuzey ve güney Amerika ve Akdeniz bölgesi olmak üzere dünya üzerinde çok geniş çaplı bir alanda yetiştiriciliği yapılan bitkidir ${ }^{13}$. Son yıllarda, nar çok işlevli olması ve insan diyetindeki besinsel faydası nedeniyle popülerlik kazanmıştır. Meyvesi, özellikle hastalık riskini azalttığı bildirilen tanenler ve özellikle fenolik bileşikler bakımından zengindir ${ }^{29}$. Nar meyve kabuğu toplam meyve ağırlığının yaklaşık \%50'sini oluşturur ve genellikle atılır. Bununla birlikte, meyve kabuğu, meyve suyundan daha yüksek miktarlarda polifenol bileşikleri içerir ve daha güçlü biyolojik aktivitelere sahiptir ${ }^{30}$. Nar kabuğu ekstresinin yüksek antioksidan kapasitesi 16, anti-kanser 12, antimikrobiyal 18, anti-enflamatuvar ${ }^{19}$ ve anti-diyabetik etkinliği bulunmaktadır.

Diyabetik hastalarda, sağlıklı bireylere göre enfeksiyon riskinin daha fazla olduğu 3 ve diyabet ile sepsisin birlikte olduğu durumlarda oksidatif stres ve sitokin miktarının artmasıyla hasarın daha güçlü hale geldiği bulunmuştur ${ }^{31-}$ 33. Sepsiste oluşan bu durumdan özellikle de akciğerin etkilendiği ve diyabetin, septik akciğer hasarını şiddetlendirdiği görülmüştür ${ }^{34}$. Sepsis ve diyabet+sepsis konusunda sitokinler ve oksidatif strese yönelik çok önemli çalışmalar vardır ${ }^{35}$. Fakat güçlü antioksidan ve anti-enflamatuvar özellikleri olan nar kabuğu ekstresinin diyabet+sepsisli olgularda etkileri henüz daha araştırılmamıştır. Bu çalışmada son zamanlarda halk arasında büyük ilgi gören nar meyvesi kabuk ekstresinin sıçanlarda diyabetik-septik akciğer hasarı üzerindeki muhtemel rolleri incelendi.

Nar kabuğu ekstresinin diyabet ve sepsisli sıçanların akciğerleri üzerindeki koruyucu etkisini araştırmak amacıyla antioksidan parametrelerin ölçümü gerçekleştirildi. Sepsiste oksidan/antioksidan dengesi bozulmuştur ${ }^{36}$. Diyabet+sepsis grubundaki verilere bakıldığında kontrol grubuna göre SOD aktivitesi ve GSH seviyesinin azaldığı, MDA seviyesinin ise arttığı görüldü. Nar kabuğu ekstresi uygulandığında ise doza bağlı olarak SOD aktivitesinin ve GSH seviyesinin yükseldiği, MDA seviyesinin ise azaldığı görüldü. Daha önce yapılan bilimsel çalışmalar bu çalışmadaki bulguları destekler niteliktedir. Nar kabuğunun doğal antioksidanları (ellagic asit, gallik asit, ellagitannen, kateşin gibi) içerdiği yapılan çalışmalarla tespit edilmiştir. Wu ve arkadaşları yüksek doz nar kabuğu ekstresinin SOD aktivitesinin ve GSH seviyesinin artırdığını ve MDA seviyesinin düşürdüğünü tespit etmişlerdir ${ }^{37}$. Başka bir bilimsel çalışmada ise metotreksat ile oluşturulan oksidatif strese karşı nar kabuğunun hem tohum hem de kabuk ekstresi $500 \mathrm{mg} / \mathrm{kg}$ dozunda uygulanmış ve SOD aktivitesinin ve GSH seviyesinin arttığı ve sağlıklıya benzer hale geldiği görülmüştür ${ }^{38}$. Daha önce yapılan başka bir çalışmada, Tavasoli S. ve arkadaşları nar suyu ekstresini sepsiste denemişlerdir ve sepsis indüksiyonu sonrası nar suyu ekstresi uygulanan grupta antioksidan enzimlerin yükseldiğini bunun yanında ilginç olarak aynı grupta serum toplam antioksidan 
durumunun (TAS) düştüğünü ve karaciğer MDA seviyelerinin yükseldiğini ileri sürmüşlerdir ${ }^{14}$.

Sepsis durumunda oksidatif stresin artmasına ek olarak sitokin seviyesinde de bir yükseliş olmaktadır. $\mathrm{Bu}$ nedenle bu çalışmada nar kabuğu ekstresinin anti-sitokin özelliklerini göstermek amaciyla TNF- $\alpha$ ve IL-1 $\beta$ mRNA ekspresyon seviyeleri ölçüldü. Kontrol grubuyla karşılaştırıldığında, sepsis grubunda TNF- $\alpha$ ve IL-1 $\beta$ mRNA ekspresyon seviyelerinin yükseldiği görüldü. Kontrol ve sepsis gruplarıyla karşılaştırıldığında, $\mathrm{DM}+\mathrm{S}$ grubundaki TNF- $\alpha$ ve IL-1 $\beta$ mRNA ekspresyon seviyelerinin arttığı görüldü. $\mathrm{DM}+\mathrm{S}$ grubuyla karşılaştırıldığında, DM+S+NKE250 ve $\mathrm{DM}+\mathrm{S}+\mathrm{NKE} 500$ guruplarındaki TNF- $\alpha$ ve IL-1 $\beta$ mRNA ekspresyon seviyesinin azaldığı ve nar kabuğu ekstresinin etkilerinin doza bağlı artış gösterdiği tespit edildi. Literatüre bakıldığında, nar ekstrelerinin içeriğindeki polifenollerin vücut homeostazı için önemli olduğu görülmektedir. Çünkü bunlar enerji düzenlemesine, kısa zincirli yağ asidi (KZYA) üretimine ve vitamin sentezine katıldıkları bilinmektedir ${ }^{13}$. KZYA'ların proliferatörle aktive edilen reseptörleri (PPAR'ları) aktive edebildiği hayvan çalışmalarında gösterilmiştir ${ }^{39}$. KZYA'lar PPAR $\alpha$ 'yı aktive ederek nükleer faktör kappa (NF-KB) gibi proenflamatuvarları bloke edebildiği ve NFKB'nin inhibisyonu da TNF- $\alpha$, IL-6, IL-1 $\beta$, COX-2 gibi enflamatuvar genlerin transkripsiyonunu azalttı̆̆ 1 bilinmektedir ${ }^{13,40}$. Enflamasyonun yoğun yaşandığı bir hastalık olan kolit modelinin oluşturulduğu bir çalışmada ise elajitanen ve elajik asitten zengin nar kabuğu ekstresi uygulaması ile TNF- $\alpha$ 'nın düştüğü ve nar kabuğunun anti-enflamatuvar özellik gösterdiği iddia edilmiştir ${ }^{41}$. Bu sonuçlar, bu araștırmada elde edilen sonuçları destekler niteliktedir.

Sonuç olarak, nar kabuğu ekstresi antioksidan ve oksidanlar arasındaki dengeyi düzenleyerek ve sitokin miktarını azaltarak anti-oksidan ve anti-enflamatuvar etkinlik göstermektedir. $\mathrm{Bu}$ sebeplerle, antioksidan/oksidan dengesinin bozulduğu ve sitokin firtınasının yoğun görüldüğü diyabet ve sepsis hastalıklarının birlikte olduğu durumlarda akciğer hasarında nar kabuğu ekstresinin kullanımı faydalı sonuçlar verecektir. $\mathrm{Bu}$ konuda ilerleyen çalışmalar yapıldıkça nar kabuğu ekstresinin koruyucu yolakları aydınlatılmış olacaktır.

Etik Kurul Kararı: Laboratuvar hayvanlarının kullanımında ve bakımında ulusal rehberlere ve etik kurallara uygun davranılmıştır. Etik kurul izni Atatürk üniversitesi deney hayvanları yerel etik kurulundan alınmıștır. Etik kurul izin belge numarasi: 2020/2-42.

Çıkar Çatışması Beyanı: Yazarlar çıkar çatışması olmadığını bildirmişlerdir.

Finansal Destek: Bu çalışma her hangi bir fon tarafından desteklenmemiştir.

Declaration of Conflicting Interests: The authors declare that they have no conflict of interest.

Financial Disclosure: No financial support was received.

\section{KAYNAKLAR}

1. Zorlu M, Helvacı A, Kıskaç M, et all. Tip 2 diyabetes mellituslu hastalarda sessiz miyokard iskemisi ve iliş̧kili risk faktörleri. Dicle Tıp Dergisi. 2010; 37: 140-4.

2. Motor S, Dokuyucu R, Sefil F, et all. Diabetes mellituslu hemodiyaliz hastalarında HbA1c ile kan glukozu düzeyleri arasındaki ilişki. Dicle Tıp Dergisi. 2013; 40: 616-20.

3. Ugan RA, Cadirci E, Halici Z, Toktay E, Cinar I. The role of urotensin-II and its receptors in sepsisinduced lung injury under diabetic conditions. European journal of pharmacology. 2018; 818: 45769.

4. Yenigün EC, Okyay GU, Pirpir A, Hondur A, Yıldırım Is. Increased mean platelet volume in type 2 diabetes mellitus. Dicle Tıp Dergisi. 2014; 41: 17-22. 
5. Tsertsvadze A, Royle P, Seedat F, et all. Community-onset sepsis and its public health burden: a systematic review. Syst Rev. 2016; 5: 81.

6. Alkan E, Ugan RA, Basar MM, et all. Role of endothelin receptors and relationship with nitric oxide synthase in impaired erectile response in diabetic rats. Andrologia. 2017; 49.

7. Türken M, Yılmaz S, Çolpan L, Aydınol B, Tuzcu AK. Tip 1 diyabetli erişkinlerde $D$ vitamini eksikliğinin serum sIL-2R, IL-6 ve TNF-alfa düzeyleri üzerine etkisi. Dicle Medical Journal/Dicle Tip Dergisi. 2015; 42.

8. Polat G, Ugan RA, Cadirci E, Halici Z. Sepsis and Septic Shock: Current Treatment Strategies and New Approaches. Eurasian Journal of Medicine. 2017; 49: 53-8.

9. Erenler AK, Yapar D, Terzi Ö. Comparison of procalcitonin and c-reactive protein in differential diagnosis of sepsis and severe sepsis in emergency department. Dicle Tıp Dergisi. 2017; 44: 175-82.

10. Cadirci E, Ugan RA, Dincer B, et all. Urotensin receptors as a new target for CLP induced septic lung injury in mice. Naunyn-Schmiedeberg's archives of pharmacology. 2019; 392: 135-45.

11. Coskun AK, Yigiter M, Oral A, et all. The effects of montelukast on antioxidant enzymes and proinflammatory cytokines on the heart, liver, lungs, and kidneys in a rat model of cecal ligation and puncture-induced TheScientificWorldJournal. 2011; 11: 1341-56.

12. Fawole OA, Makunga NP, Opara UL. Antibacterial, antioxidant and tyrosinase-inhibition activities of pomegranate fruit peel methanolic extract. BMC Complement Altern Med. 2012; 12: 200.

13. Vucic V, Grabez M, Trchounian A, Arsic A. Composition and Potential Health Benefits of Pomegranate: A Review. Curr Pharm Des. 2019; 25: 1817-27.

14. Tavasoli S, Eghtesadi S, Vafa M, et all. High Dose Pomegranate Extract Suppresses Neutrophil Myeloperoxidase and Induces Oxidative Stress in a Rat Model of Sepsis. Int J Vitam Nutr Res. 2019; 89: 271-84.
15. Akhtar S, Ismail T, Fraternale D, Sestili P. Pomegranate peel and peel extracts: chemistry and food features. Food Chem. 2015; 174: 417-25.

16. Gozlekci S, Saracoglu O, Onursal E, Ozgen M. Total phenolic distribution of juice, peel, and seed extracts of four pomegranate cultivars. Pharmacogn Mag. 2011; 7: 161-4.

17. Yayla M, Çetin D, Demirbağ Ç, Kılıçle PA. Nar Kabuğu Ekstresinin Sıçanlarda Paklitakselle İndüklenen Primer Nöron Hasarına Karşı Koruyucu Etkisi. Kafkas Tıp Bilimleri Dergisi. 8: 149-57.

18. McCarrell EM, Gould SW, Fielder MD, et all. Antimicrobial activities of pomegranate rind extracts: enhancement by addition of metal salts and vitamin C. BMC Complement Altern Med. 2008; 8: 64.

19. Lin CC, Hsu YF, Lin TC. Effects of punicalagin and punicalin on carrageenan-induced inflammation in rats. Am J Chin Med. 1999; 27: 371-6.

20. Wang LJ, Weller CL. Recent advances in extraction of nutraceuticals from plants. Trends Food Sci Tech. 2006; 17: 300-12.

21. Bahçeci S, Canoruç N, Nergiz Y, ve ark. Alloksan İle Oluşturulan Deneysel Diyabetin KardiyoVasküler Sistem Üzerindeki Akut Etkilerinin Işık Mikroskobik Düzeyde İncelenmesi. Dicle Tıp Dergisi. 2007; 34: 111-5.

22. Çavuşoğlu T, Çiftçi ÖD, Çağıltay E, ve ark. Diyabetik kardiyomiyopati sıçan modelinde oksitosin etkilerinin histolojik ve biyokimyasal olarak incelenmesi. Dicle Tıp Dergisi. 2017; 44: 13543.

23. Tatar A, Parlak SN, Yayla M, et all. Effects of allergic rhinitis and desloratadine on the submandibular gland in a rat allergy model. Int Forum Allergy Rhinol. 2015; 5: 1164-9.

24. Liu LM, Zhao L, Liang DY, et al. Effects of urotensin-II on cytokines in early acute liver failure in mice. World journal of gastroenterology. 2015; 21 :3239-44.

25. Bayir Y, Un H, Ugan RA, et al. The effects of Beeswax, Olive oil and Butter impregnated bandage on burn wound healing. Burns. 2019; 45: 1410-7. 
26. Livak KJ, Schmittgen TD. Analysis of relative gene expression data using real-time quantitative PCR and the 2(-Delta Delta C(T)) Method. Methods. 2001; 25: 402-8.

27. George D, Mallery M. SPSS for windows step by step: A simple study guide and reference, 17.0 update. 10 ed. Boston: Pearson; 2010.

28. Aktürk Z, Acemoğlu H. Sağlık Çalışanları İçin Araştırma Pratik İstatistik. Erzurum; 2010.

29. Jaiswal V, DerMarderosian A, Porter JR. Anthocyanins and polyphenol oxidase from dried arils of pomegranate (Punica granatum L.). Food Chem. 2010; 118: 11-6.

30. Al-Said FA, Opara LU, Al-Yahyai RA. Physicochemical and textural quality attributes of pomegranate cultivars (Punica granatum L.) grown in the Sultanate of Oman. J Food Eng. 2009; 90: 12934.

31. Schuetz P, Yano K, Sorasaki M, et all. Influence of diabetes on endothelial cell response during sepsis. Diabetologia. 2011; 54: 996-1003.

32. Demir AD, Erenberk U, Özgen İT, et all. Total antioxidant and oxidant status in obese children without insulin resistance. Dicle Med J. 2014; 41: 257-61.

33. Ceylan-Işık AF, Erdoğan-Tulmaç ÖB, Aktan F, Arı $\mathrm{N}$, Ozansoy G. Östrojen Yerine Koyma Tedavisinin Overektomili ve Overektomili-Diyabetik Sıçanlarda Doku Lipid Peroksidasyonu ve Antioksidan Enzim Aktiviteleri Üzerine Etkisi. Dicle Tıp Dergisi.

34. Bernard GR, Artigas A, Brigham KL, et all. Report of the American-European consensus conference on ARDS: definitions, mechanisms, relevant outcomes and clinical trial coordination. The Consensus Committee. Intensive care medicine. 1994; 20: 22532.

35. Laszlo I, Trasy D, Molnar Z, Fazakas J. Sepsis: From Pathophysiology to Individualized Patient Care. J Immunol Res. 2015.

36. Cimen B, Cimen L, Cetin I, Cetin A. Alpha-lipoic acid alleviates lipopolysaccharide-induced liver damage in rats via antioxidant effect. Dicle Tip Dergisi. 2019; 46: 125-32.

37. $\mathrm{Wu} \mathrm{Y}, \mathrm{Zhu} \mathrm{CP}$, Zhang Y, Li Y, Sun JR. Immunomodulatory and antioxidant effects of pomegranate peel polysaccharides on immunosuppressed mice. Int J Biol Macromol. 2019; 137: 504-11.

38. Doostan F, Vafafar R, Zakeri-Milani P, et all. Effects of Pomegranate (Punica Granatum L.) Seed and Peel Methanolic Extracts on Oxidative Stress and Lipid Profile Changes Induced by Methotrexate in Rats. Adv Pharm Bull. 2017; 7: 269-74.

39. den Besten G, Bleeker A, Gerding A, et all. ShortChain Fatty Acids Protect Against High-Fat DietInduced Obesity via a PPARgamma-Dependent Switch From Lipogenesis to Fat Oxidation. Diabetes. 2015; 64: 2398-408.

40. Ricote M, Li AC, Willson TM, Kelly CJ, Glass CK. The peroxisome proliferator-activated receptorgamma is a negative regulator of macrophage activation. Nature. 1998; 391: 79-82.

41. Rosillo MA, Sanchez-Hidalgo M, Cardeno A, et all. Dietary supplementation of an ellagic acid-enriched pomegranate extract attenuates chronic colonic inflammation in rats. Pharmacol Res. 2012; 66: 23542. 